\title{
Assessment of Solar Energy Resource in Niger Delta: Case Study Port Harcourt and Yenagoa
}

\author{
Oniyeburutan Ebakumo Thomas \\ Dept of Electrical Electronic Engineering, \\ University of Port Harcourt, \\ Rivers State, Nigeria.
}

\author{
Gaius Paul Ekanem \\ Dept of Electrical Electronic Engineering, \\ University of Port Harcourt, \\ Rivers State, Nigeria.
}

\begin{abstract}
This paper presents an assessment of solar energy resources in Niger Delta case study of Port Harcourt and Yenagoa. The use of alternative sources of electricity is gaining popularity in different parts of the world especially with lots of interest being focused on harnessing solar energy. This work point out the irradiance viability and characteristic of solar sunshine per hour in Port Harcourt and Yenagoa City in the Niger Delta region of Nigeria. Several literatures were reviewed. Data were collected from the Nigerian Meteorological Agency (NiMET) and were analyzed. Matlab/Simulink was employed in the analyses and the output results were discussed. The result shows that Yenagoa City has more solar energy viability than Port Harcourt.
\end{abstract}

Keywords: Renewable energy, solar energy, viability, Niger Delta, MATLAB

\subsection{INTRODUCTION}

The use of alternative sources of electricity is gaining popularity in different parts of the world especially with lots of interest being focused on harnessing solar energy. To make use of this energy effectively, a proper knowledge of its behavior and characteristic has to be understood. Solar energy is available at any part of the world, but the potential of energy available varies with respect to geographical locations, times and seasons. The amount of solar irradiance falling on any location determines the solar energy available at that particular geographical. The solar radiation intensity falling on a surface defines solar irradiance and it is measured in $\mathrm{N} / \mathrm{m}^{2}$ or $\mathrm{KW} / \mathrm{m}^{2}$. Some researchers and authors refer to it as isolation value. The average radiation intensity falling on an imaginary object or surface, perpendicular to the sun's ray and at the edge of the earth's atmosphere is called the solar constant (Isc).

Solar constant is sometimes misleading because of the earth's elliptical orbit the intensity of the solar radiation falling on the earth changes by about $7 \%$ between January 1 st, when the earth is nearest the sun and July 3rd, when the earth is furthest from the sun. When an average yearly value is taken the solar constant will be equals $1367 \mathrm{~W} / \mathrm{m}^{2} / \mathrm{s}$. This value is still not accurate because the output of the sun changes by about $0.25 \%$ due to sunspot cycles [1]. According to [2] only about 13 percent of this radiation reaching the earth may be absorbed by the atmosphere and 12 percent scattered. This implies that the direct radiation available at the surface of the earth near the tropics in the middle of a cloudless day is about 75 percent of the level of the radiations at the surface of the atmosphere, which gives us about $1 \mathrm{KJ} / \mathrm{m}^{2} / \mathrm{s}$.
This is believed to be true if the earth is assumed to be an immovable body. Also it is known from our basic knowledge of physics that we can receive up to $1,367 \mathrm{~W} / \mathrm{m}^{2} / \mathrm{s}$ for a part of each day since the earth rotates. The solar radiation reaching the surface of the earth changes for different geographical locations at a given season and time. This is the reason why meteorological information of any geographical location is of utmost importance before modeling a solar system for that location. [1] revealed that geographical factors like isolation value are required for a proper design of a solar power system. The Nation Nigeria is located at the western region of Africa at latitude between $4^{\circ} \mathrm{N}$ and $13^{\circ} \mathrm{N}$ and longitude between $3^{\circ} \mathrm{E}$ and $15^{\circ} \mathrm{W}$. The country is made up of 36 states and a Federal capital territory. It is important to note that one can attach an average value for every geographic data when considering a location as reference, but the fact remains that there are still differences in the amount of energy reaching different locations within her.

Studies on how a particular geographical location encounters changes in solar energy distribution have shown that the various 36 states that make up Nigeria possess different meteorological data which accounts for the variation in solar energy distribution/radiation.

It is known generally that the Northern region of Nigeria is always hotter than every other region while plateau and its environs are always cold. The eastern, western and southern regions have slightly moderate weather condition. All these are as a result of variation in solar irradiance brought about by variation in their position on the earth surface.

The southern part of Nigeria is known for oil rich natural resources, and its aquatic source of avenue for its economic 
growth. Solar renewable energies have not been harnessed. Electricity challenges in Nigeria particularly in the Niger Delta Region is high. There are various renewable energies in this region that is left untouched that would have help solve the growing demand of energy challenge.

This paper point out theoretically the irradiance viability and characteristic of sunshine per hour in Port Harcourt and Yenagoa City in the Niger Delta region of Nigeria. The study also help us to make decision in harnessing solar energy from the Niger Delta region particularly Port Harcourt and Yenagoa city.

The scope of this study is the assessment of solar energy resource in Niger Delta: case study of Port Harcourt and Yenegoa. Sunshine hours were used to determine the available power.

\section{THEORETICAL REVIEW}

\subsection{SOLAR ENERGY}

Solar energy is radiant light and heat from the Sun that is converted into used using a range of techniques such as solar heating, solar architecture, photovoltaic, solar thermal energy, molten salt power plants and artificial photosynthesis [3]. It is an essential source of renewable energy and its techniques are broadly characterized as either passive solar or active solar depending on how they trap and distribute solar energy or convert it into solar power. Active solar technologies include the use of photovoltaic $\underline{\text { systems, }}$ concentrated solar power and solar water heating to harness the energy. Passive solar technologies include orienting a building to the Sun, selecting materials with favorable thermal mass or light dispersing properties and designing spaces that naturally spread air.

The huge amount of solar energy available makes it a highly appealing or attractive source of electricity. The 2,000 World Energy Assessment programme of the United Nation Development reveals that the annual potential of solar energy was about 1,575 - 49,837 exajoules(EJ). This is at different times larger than the total world energy consumption, which was $559.8 \mathrm{EJ}$ in 2012 [4].

In 2011, the International Energy Agency also reveals that the development of inexhaustible, affordable and clean solar energy techniques will have large long term benefits. Energy security in various countries will be increase through reliance on an indigenous, affordable and mostly import independent resource, reduce pollution, enhance sustainability, lower the costs of mitigating global warming, and keep fossil fuel prices lower. These benefits are global. Though its early deployment is costly but these costs should be considered learning investments, considering the long term benefits [3].The utilization of solar energy depends on the appropriate technology and its availability [5]. For centuries, the idea of using the sun's power as a source of solar energy has held scientist to grips [6]. Also, for most of its evolution, mankind has relied on the sun as a source of energy since it is constantly replenished. When fire was discovered as a source for the provision of heat and for the processing of food, the demand for energy increases, these demands were met by constantly renewed sources.

Later other sources of renewable energy such as water and wind powers were harnessed to the service of mankind. Throughout the early phase of human development one of the key constraint of mankind was the availability of the readily renewable sources of energy, this has affected the size and distribution of population [7]. The sun radiates huge amount of energy per year. It radiates energy in one year than people have used since the beginning of times.

It takes about millions of years for the energy in the sun's core to find its way to the surface, and then about another eight (8) minutes to travel to the earth. Solar energy travels to the earth at the speed of light, which is about $3.0 \times 10^{8} \mathrm{~m} / \mathrm{s}$ [8]. Small amount of the energy radiated by the sun strikes the earth surface, one part in two million. Yet, this amount of energy is large. Huge amount of solar energy strikes the earth to supply its energy needs. It was discovered in 1831 that the sun's energy could produce a photovoltaic effect [8]. In 1878, the first solar energy to mechanical energy conversion system was demonstrated, when sunlight was concentrated by focusing a collector on a steam boiler that ran a small printing press [9].

In 1980s, selenium photovoltaic cells were developed, that were able to convert sunlight into electricity but how the conversion was done was not thoroughly understood, they had 1- $2 \%$ efficiency. Solar power therefore has been a curiosity over the years. In 1901, larger focusing collector in truncated cone form generate steam for a $4.5 \mathrm{hp}$ engine. But between 1907 and 1911, solar steam engine of different horse power that were used for pumping water was built. [10] has it that by mid 1950s the efficiency was improved by $45 \%$ and later $11 \%$ increased was achieved with silicon photovoltaic cells. As a result, interest in solar power intensified. During the late 1950 s and 1960s, the space program took active role in the development of photovoltaic. The cells were perfect sources of electric power for satellite, they were lightweight, rugged, and could meet the power requirements reliably. Unfortunately, the cells were not practical on earth due to the high cost of making them efficient and lightweight [11]. Consequently, further research was needed.

Climate is the average weather condition of a place over a given period of time. It is known primarily by distance from the coast and secondarily by elevation. [6]. Nigeria is entirely between the equators, Nigeria's electrical energy consumption in the year 2001 is $15 \times 106 \mathrm{kWh}$ and the tropic of cancer [12]. Its climate changes from tropical to subtropical. There are two main seasons in Nigeria; the dry season which last from October to March and the rainy season which last from April to October. It is hot and dry in the northern part. Rainy season extends between April and September. It is hot and wet in the south. Rainy season extends between March and 
December. From December to March there is a long dry season. Temperatures at the coast rarely rise above $32{ }^{\circ} \mathrm{C}$. The north is drier with temperature ranging between $32{ }^{\circ} \mathrm{C}$ and 42 ${ }^{\circ} \mathrm{C}$, humidity of about $95 \%,[12]$. The sun has enough hydrogen to burn for about 10 million years, it has been shining for about 4.5 billion years. All energy on earth results from the sun's energy directly or indirectly. Green plants absorbed the sun's ultraviolet rays to make their food. The dead, buried, decayed plants and trees over centuries turned into coal, oil and gas. Waterpower also comes from the sun; water is evaporated from the earth by the sun and this produces rainfall that fills the seas, lakes, rivers, oceans and reservoir.

Wind power also comes from the sun, the difference in heating of the earth globally results in kinetic energy [13]. The availability of solar energy in a particular region at present and at some other time in the future is the first concern to the designer of solar energy system. The availability of solar energy on earth is determined by the geographical location and time scale. The sunshine hours and consequently the radiations in different zones differ. The sun's power reaching the earth is typically about $1000 \mathrm{~W} / \mathrm{m}^{2}$ [14].

\subsection{SOLAR THERMAL}

Solar thermal is the direct application of solar energy to produce heat. Solar thermal application has been dated back to ages, where the sun were used for drying and so on, common in the equatorial region where people have programmed themselves to sun drying of personal effects such as drying of agricultural commodities, clothing and so on resulting to various researches in solar thermal equipment like water heaters, Oven, cabinet dryers, hatchery, among others. In Nigeria, solar thermal have been developed for various purposes; some of these are chick brooding devices, solar cookers, solar pulverizes, [15]. Regarding the drying of Agricultural produce, there are four (4) major drying technologies, these are namely: open air drying, fire wood/fuel drying, electrical drying and solar drying [16].

\subsection{SOLAR PV}

Here, solar cells are used to convert solar radiation in electricity. These include Water Pumping for Irrigation in the rural areas, lightings and other purposes. The United Nation Commission on Sustainable Development has called for much wider access to sustainable energy as a prerequisite for reducing poverty to about $50 \%$ by the year 2015 and all world leader reaffirmed in the year 2005 world summit in New York. By sustainable energy, it means energy produced and used in a way that supports human development over the long term in all its social, economic and environmental development [17]. There can be immediate and widespread deployment and application of solar energy which can easily cover large area of Nigeria especially rural and river-rine areas because of many advantages of solar energy application over the present energy supply sources; especially when decentralized application is involved. Decentralization of Solar Energy installation means individual acquisition, utilization and application of the system. In this system, no high or low tension transformer will be required, high or low tension wiring, equipment and logistic will not be involved in the distribution of the energy, which means the solar PV (panels) can easily be carried, deployed and installed on individual establishment and premises in any part of the country at low cost within a very short period.

\subsection{REVIEW OF PREVIOUS WORKS}

[18] developed a model for prediction of solar energy in Nigeria using an artificial neural network model. Meteorological data from the National Aeronautics and space administration (NASA) for a period of 10 years from 1983 to 1993 of 195 cities in Nigeria were used. Geo-satellite data base were used for training and testing the network. He used meteorological data such as monthly sunshine duration, relative humidity, mean temperature, latitude and longitude were used as inputs to the network while the solar radiation intensity was used as the output of the network. He reported in his work that the monthly mean solar radiation potential in the North ranges from $7.01-5.62 \mathrm{kWh} / \mathrm{m}^{2}$ while in the South it ranges from $5.43-3.54 \mathrm{kWh} / \mathrm{m}^{2}$ [17] proposed an empirical model for estimating global solar radiation on horizontal surfaces for seven cities in Nigeria; Benin, Nsukka, Lagos, Kastina, Yola, and Abuja. He reported that, these cities from March through August ( rainy season) experienced a decrease in the horizontal global solar radiation. Benin City was seen to have the lowest monthly mean daily horizontal global solar radiation of about $3.46 \mathrm{kWh} / \mathrm{m}^{2} /$ day in July. They also reported that the variation of daily horizontal global solar radiation with month of the year in Kastina varies from other cities because Kastina is located at longitude $7.6^{\circ} \mathrm{E}$, and latitude $13.0^{\circ} \mathrm{N}$. [18] developed a number of multi-linear regression equation based on Angstrom equation to predict the connection between global solar radiations with one or more combinations of some weather parameters for Iseyin Nigeria for five years. He reported that the expression with the highest value of correlation coefficient (r), least value of root mean square error (RMSE), mean bias error (MBE), and mean percentage error (MPE) was adopted for the estimation of different geographical location in Nigeria.

The motivating factor behind this work was the quest for meteorological models and data to model solar power systems. Meteorological data from four (4) different states were studied, evaluated to establish solar isolation potential, models and comparison.

This work adopts statistical method with the help of MATLAB in achieving the aim of this study. 


\subsection{METHODOLOGY}

The assessment of solar energy resource in Niger delta using Port Harcourt and Yenagoa as case study. The data of sunshine hours for the year 2015, 2016 and 2017 were used in correlating the data's used in running the simulation in MATLAB

The simulation was run in MATLAB to show the month in the year that the sunshine was at its maximum (peak) and minimum (low), this aid in the feasibility of harnessing the solar energy in Port Harcourt and in Yenagoa.

Table 3.1: Sunshine Per hour for Yenagoa

\begin{tabular}{|l|l|l|l|}
\hline Months & $2015(\mathrm{hr})$. & $2016(\mathrm{hr})$. & $2017(\mathrm{hr})$. \\
\hline Jan & 3.9 & 6.3 & 4.9 \\
\hline Feb & 6.1 & 3.6 & 4.9 \\
\hline Mar & 4.5 & 5 & 5.6 \\
\hline Apr & 6 & 3.8 & 4.4 \\
\hline May & 5 & 4.6 & 5 \\
\hline Jun & 4.1 & 3.8 & 1.9 \\
\hline Jul & 3 & 2.9 & 1.3 \\
\hline Aug & 3.2 & 2.1 & 1.4 \\
\hline Sep & 2.7 & 3.2 & 1.9 \\
\hline Oct & 4 & 4 & 4 \\
\hline Nov & 6.3 & 6.3 & 5.7 \\
\hline Dec & 5.5 & 6 & 5.3 \\
\hline
\end{tabular}

Source: Nigerian Meteorological Agency (NiMET) [19]

Table 3.2: Power Available, using PV module size of $200 \mathrm{~W}$ in

Yenagoa.

\begin{tabular}{|c|c|c|c|c|c|c|c|c|c|}
\hline on & $\begin{array}{c}20 \\
15 \\
(\mathrm{~h} \\
\mathrm{r})\end{array}$ & $\begin{array}{c}20 \\
16 \\
(\mathrm{~h} \\
\mathrm{r}) \\
\end{array}$ & $\begin{array}{c}20 \\
17 \\
(\mathrm{~h} \\
\mathrm{r}) \\
\end{array}$ & $\begin{array}{l}\mathrm{A} \\
\mathrm{V} \\
\mathrm{E} \\
\mathrm{R} \\
\mathrm{A} \\
\mathrm{G} \\
\mathrm{E} \\
\text { (h } \\
\mathrm{r})\end{array}$ & $\begin{array}{l}\text { PV } \\
=2 \\
00 \\
\text { W, } \\
\text { PO } \\
\text { W } \\
\text { ER } \\
\text { GE } \\
\text { NE } \\
\text { RA } \\
\text { TE } \\
\text { D } \\
\text { IN } \\
\text { A } \\
\text { D } \\
\text { A } \\
\text { Y } \\
\text { (W } \\
\text { hr) }\end{array}$ & $\begin{array}{l}\text { PV } \\
=20 \\
0 W, \\
\text { PO } \\
\text { WE } \\
\text { R } \\
\text { GE } \\
\text { NE } \\
\text { RA } \\
\text { TE } \\
\text { D } \\
\text { IN } \\
\text { A } \\
\text { MO } \\
\text { NT } \\
\text { H } \\
\text { (Wh } \\
\text { r) }\end{array}$ & $\begin{array}{l}\text { USI } \\
\text { NG } \\
\text { PV } \\
=20 \\
\text { 0W, } \\
\text { PO } \\
\text { WE } \\
\text { R } \\
\text { LO } \\
\text { SS } \\
\text { ES } \\
\text { (W } \\
\text { hr) }\end{array}$ & $\begin{array}{l}\text { USI } \\
\text { NG } \\
\text { PV } \\
=20 \\
0 W, \\
\text { AV } \\
\text { AIL } \\
\text { AB } \\
\text { LE } \\
\text { PO } \\
\text { WE } \\
\text { R } \\
\text { (Wh } \\
\text { r) }\end{array}$ & $\begin{array}{l}\text { LO } \\
\text { AD } \\
\text { OF } \\
200 \\
\text { W, } \\
\text { HO } \\
\text { UR } \\
\text { PO } \\
\text { WE } \\
\text { R } \\
(\mathrm{hr})\end{array}$ \\
\hline $\begin{array}{l}\text { JA } \\
\mathrm{N}\end{array}$ & $\begin{array}{r}3 . \\
9 \\
\end{array}$ & $\begin{array}{r}6 . \\
3 \\
\end{array}$ & $\begin{array}{r}4 . \\
9 \\
\end{array}$ & $\begin{array}{l}5 . \\
0\end{array}$ & $\begin{array}{r}10 \\
00 . \\
0\end{array}$ & $\begin{array}{r}310 \\
00 \\
\end{array}$ & $\begin{array}{r}930 \\
0 \\
\end{array}$ & $\begin{array}{r}217 \\
00 \\
\end{array}$ & $\begin{array}{r}108 \\
.5 \\
\end{array}$ \\
\hline $\begin{array}{l}\mathrm{FE} \\
\mathrm{B}\end{array}$ & $\begin{array}{r}6 . \\
1\end{array}$ & $\begin{array}{l}3 . \\
6\end{array}$ & $\begin{array}{r}4 . \\
9\end{array}$ & $\begin{array}{l}4 . \\
9\end{array}$ & $\begin{array}{c}98 \\
0.0\end{array}$ & $\begin{array}{r}284 \\
20\end{array}$ & $\begin{array}{r}852 \\
6\end{array}$ & $\begin{array}{r}198 \\
94\end{array}$ & $\begin{array}{r}99 . \\
5\end{array}$ \\
\hline $\begin{array}{l}\mathrm{M} \\
\mathrm{A}\end{array}$ & $\begin{array}{r}4 . \\
5\end{array}$ & 5 & $\begin{array}{c}5 . \\
6\end{array}$ & $\begin{array}{l}5 . \\
0\end{array}$ & $\begin{array}{c}10 \\
00 .\end{array}$ & $\begin{array}{r}310 \\
00\end{array}$ & $\begin{array}{r}930 \\
0\end{array}$ & $\begin{array}{r}217 \\
00\end{array}$ & $\begin{array}{r}108 \\
.5\end{array}$ \\
\hline
\end{tabular}

\begin{tabular}{|l|r|r|r|r|r|r|r|r|r|}
\hline $\mathrm{R}$ & & & & & 0 & & & & \\
\hline & & & & & 10 & & & & \\
$\mathrm{~A}$ & & 3. & 5. & 5. & 20. & 306 & 918 & 214 & 107 \\
$\mathrm{PR}$ & 6 & 8 & 6 & 1 & 0 & 00 & 0 & 20 & .1 \\
\hline $\mathrm{M}$ & & & & & & & & & \\
$\mathrm{A}$ & & 4. & & 4. & 98 & 303 & 911 & 212 & 106 \\
$\mathrm{Y}$ & 5 & 6 & 5 & 9 & 0.0 & 80 & 4 & 66 & .3 \\
\hline $\mathrm{JU}$ & 4. & 3. & 4. & 4. & 82 & 246 & 738 & 172 & 86. \\
$\mathrm{~N}$ & 1 & 8 & 4 & 1 & 0.0 & 00 & 0 & 20 & 1 \\
\hline $\mathrm{JU}$ & & 2. & 1. & 2. & 42 & 130 & 390 & 911 & 45. \\
$\mathrm{~L}$ & 3 & 9 & 3 & 4 & 0.0 & 20 & 6 & 4 & 6 \\
\hline $\mathrm{A}$ & & & & & & & & & \\
$\mathrm{U}$ & 3. & 2. & 1. & 2. & 44 & 136 & 409 & 950 & 47. \\
$\mathrm{G}$ & 2 & 1 & 4 & 2 & 0.0 & 40 & 2 & 8 & 5 \\
\hline $\mathrm{SE}$ & 2. & 3. & 1. & 2. & 52 & 156 & 468 & 109 & 54. \\
$\mathrm{P}$ & 7 & 2 & 9 & 6 & 0.0 & 00 & 0 & 20 & 6 \\
\hline $\mathrm{O}$ & & & & & & & & & \\
$\mathrm{C}$ & & & & 4. & 80 & 248 & 744 & 173 & 86. \\
$\mathrm{~T}$ & 4 & 4 & 4 & 0 & 0.0 & 00 & 0 & 60 & 8 \\
\hline $\mathrm{N}$ & & & & & 12 & & & & \\
$\mathrm{O}$ & 6. & 6. & 5. & 6. & 20. & 366 & 109 & 256 & 128 \\
$\mathrm{~V}$ & 3 & 3 & 7 & 1 & 0 & 00 & 80 & 20 & .1 \\
\hline $\mathrm{D}$ & & & & & 11 & & & & \\
$\mathrm{E}$ & 5. & & 5. & 5. & 20. & 347 & 104 & 243 & 121 \\
$\mathrm{C}$ & 5 & 6 & 3 & 6 & 0 & 20 & 16 & 04 & .5 \\
\hline
\end{tabular}

Table 3.3: Sunshine Per hour for Port Harcourt

\begin{tabular}{|l|l|l|l|}
\hline MONTHS & 2015 (hr.) & 2016 (hr.) & 2017 (hr.) \\
\hline Jan & 4.4 & 5.8 & 5.2 \\
\hline Feb & 4 & 5.0 & 6.2 \\
\hline Mar & 3.9 & 4.1 & 4.2 \\
\hline Apr & 4.8 & 5.4 & 5.3 \\
\hline May & 5.5 & 4.9 & 5.1 \\
\hline Jun & 4.2 & 4.0 & 3.0 \\
\hline Jul & 2.7 & 2.5 & 3.1 \\
\hline Aug & 2 & 2.9 & 1.3 \\
\hline Sep & 2.8 & 3.1 & 2.0 \\
\hline Oct & 3.6 & 4.3 & 2.8 \\
\hline Nov & 4.6 & 5.6 & 5.8 \\
\hline Dec & 4.1 & 5.7 & 5.7 \\
\hline Sourc: Nigen & Meorogica Agency (NIMET) \\
\hline
\end{tabular}

Source: Nigerian Meteorological Agency (NIMET) 
Table 3.4: Power Available, using PV Module size of 200W in Port Harcourt.

\begin{tabular}{|c|c|c|c|c|c|c|c|c|c|}
\hline $\begin{array}{l}\mathrm{M} \\
\text { on } \\
\text { th }\end{array}$ & $\begin{array}{l}20 \\
15 \\
\text { (h } \\
\mathrm{r})\end{array}$ & $\begin{array}{r}20 \\
16 \\
(\mathrm{hr} \\
)\end{array}$ & $\begin{array}{r}20 \\
17 \\
(\mathrm{hr} \\
)\end{array}$ & $\begin{array}{c}\text { AV } \\
\text { ER } \\
\text { AG } \\
\text { E } \\
(\mathrm{hr})\end{array}$ & $\begin{array}{l}\text { PV } \\
=20 \\
0 W \\
\text { PO } \\
\text { WE } \\
\text { R } \\
\text { GE } \\
\text { NE } \\
\text { RA } \\
\text { TE } \\
\text { D } \\
\text { IN } \\
\text { A } \\
\text { DA } \\
\text { Y } \\
\text { (W } \\
\text { hr) }\end{array}$ & $\begin{array}{l}\text { PV } \\
=20 \\
0 W \\
\text { PO } \\
\text { WE } \\
\text { R } \\
\text { GE } \\
\text { NE } \\
\text { RA } \\
\text { TE } \\
\text { D } \\
\text { IN } \\
\text { A } \\
\text { MO } \\
\text { NT } \\
\text { H } \\
\text { (W } \\
\text { hr) }\end{array}$ & $\begin{array}{l}\text { US } \\
\text { IN } \\
\text { G } \\
\text { PV } \\
=2 \\
00 \\
\text { W, } \\
\text { PO } \\
\text { W } \\
\text { ER } \\
\text { L } \\
\text { OS } \\
\text { SE } \\
\text { S } \\
\text { (W } \\
\text { hr) }\end{array}$ & $\begin{array}{l}\text { USI } \\
\text { NG } \\
\text { PV } \\
=20 \\
\text { OW, } \\
\text { AV } \\
\text { AIL } \\
\text { AB } \\
\text { LE } \\
\text { PO } \\
\text { WE } \\
\text { R } \\
\text { (W } \\
\text { hr) }\end{array}$ & $\begin{array}{l}\text { LO } \\
\text { AD } \\
\text { OF } \\
200 \\
\text { W, } \\
\text { HO } \\
\text { UR } \\
\text { PO } \\
\text { W } \\
\text { ER } \\
(\mathrm{hr})\end{array}$ \\
\hline $\begin{array}{l}\text { JA } \\
N\end{array}$ & $\begin{array}{r}4 . \\
4\end{array}$ & 5.8 & 5.2 & 5.1 & $\begin{array}{r}102 \\
0\end{array}$ & $\begin{array}{r}316 \\
20\end{array}$ & $\begin{array}{l}94 \\
86\end{array}$ & $\begin{array}{r}221 \\
34\end{array}$ & $\begin{array}{r}110 \\
.7\end{array}$ \\
\hline $\begin{array}{l}\mathrm{FE} \\
\mathrm{B}\end{array}$ & 4 & 5.0 & 6.2 & 5.1 & $\begin{array}{r}102 \\
0\end{array}$ & $\begin{array}{r}285 \\
60\end{array}$ & $\begin{array}{l}85 \\
68\end{array}$ & $\begin{array}{r}199 \\
92\end{array}$ & 100 \\
\hline $\begin{array}{l}\mathrm{M} \\
\mathrm{A} \\
\mathrm{R}\end{array}$ & $\begin{array}{l}3 . \\
9\end{array}$ & 4.1 & 4.2 & 4.1 & 820 & $\begin{array}{r}254 \\
20\end{array}$ & $\begin{array}{l}76 \\
26\end{array}$ & $\begin{array}{r}177 \\
94\end{array}$ & 89 \\
\hline $\begin{array}{l}\mathrm{A} \\
\mathrm{P} \\
\mathrm{R}\end{array}$ & $\begin{array}{r}4 . \\
8\end{array}$ & 5.4 & 5.3 & 5.2 & $\begin{array}{r}104 \\
0\end{array}$ & $\begin{array}{r}312 \\
00\end{array}$ & $\begin{array}{l}93 \\
60\end{array}$ & $\begin{array}{r}218 \\
40\end{array}$ & $\begin{array}{r}109 \\
.2\end{array}$ \\
\hline $\begin{array}{l}\mathrm{M} \\
\mathrm{A} \\
\mathrm{Y}\end{array}$ & $\begin{array}{r}5 . \\
5\end{array}$ & 4.9 & 4.1 & 4.8 & 960 & $\begin{array}{r}297 \\
60\end{array}$ & $\begin{array}{l}89 \\
28\end{array}$ & $\begin{array}{r}208 \\
32\end{array}$ & $\begin{array}{r}104 \\
.1\end{array}$ \\
\hline $\begin{array}{l}\mathrm{JU} \\
\mathrm{N}\end{array}$ & $\begin{array}{r}4 . \\
2\end{array}$ & 4.0 & 3.0 & 3.7 & 740 & $\begin{array}{r}222 \\
00\end{array}$ & $\begin{array}{l}66 \\
60\end{array}$ & $\begin{array}{r}155 \\
40\end{array}$ & $\begin{array}{r}77 . \\
7\end{array}$ \\
\hline $\begin{array}{l}\mathrm{JU} \\
\mathrm{L}\end{array}$ & $\begin{array}{r}2 . \\
7\end{array}$ & 2.5 & 3.1 & 2.8 & 560 & $\begin{array}{r}173 \\
60 \\
\end{array}$ & $\begin{array}{l}52 \\
08\end{array}$ & $\begin{array}{r}121 \\
52 \\
\end{array}$ & $\begin{array}{r}60 \\
8\end{array}$ \\
\hline $\begin{array}{l}\mathrm{A} \\
\mathrm{U} \\
\mathrm{G}\end{array}$ & 2 & 2.9 & 1.3 & 2.1 & 420 & $\begin{array}{r}130 \\
20\end{array}$ & $\begin{array}{l}39 \\
06\end{array}$ & $\begin{array}{r}911 \\
4\end{array}$ & $\begin{array}{r}45 \\
6\end{array}$ \\
\hline $\begin{array}{l}\mathrm{SE} \\
\mathrm{P}\end{array}$ & $\begin{array}{r}2 . \\
8\end{array}$ & 3.1 & 2.0 & 2.6 & 520 & $\begin{array}{r}156 \\
00\end{array}$ & $\begin{array}{l}46 \\
80\end{array}$ & $\begin{array}{r}109 \\
20\end{array}$ & $\begin{array}{r}54 \\
6\end{array}$ \\
\hline $\begin{array}{l}\mathrm{O} \\
\mathrm{C} \\
\mathrm{T}\end{array}$ & $\begin{array}{c}3 . \\
6\end{array}$ & 4.3 & 2.8 & 3.6 & 720 & $\begin{array}{r}223 \\
20\end{array}$ & $\begin{array}{l}66 \\
96\end{array}$ & $\begin{array}{r}156 \\
24\end{array}$ & $\begin{array}{r}78 \\
1\end{array}$ \\
\hline $\begin{array}{l}\mathrm{N} \\
\mathrm{O} \\
\mathrm{V}\end{array}$ & $\begin{array}{r}4 . \\
6\end{array}$ & 5.6 & 5.8 & 5.3 & $\begin{array}{r}106 \\
0\end{array}$ & $\begin{array}{r}318 \\
00\end{array}$ & $\begin{array}{l}95 \\
40\end{array}$ & $\begin{array}{r}222 \\
60\end{array}$ & $\begin{array}{r}111 \\
.3\end{array}$ \\
\hline $\begin{array}{l}\mathrm{D} \\
\mathrm{E} \\
\mathrm{C}\end{array}$ & $\begin{array}{r}4 . \\
1\end{array}$ & 5.7 & 5.7 & 5.2 & $\begin{array}{r}104 \\
0\end{array}$ & $\begin{array}{r}322 \\
40\end{array}$ & $\begin{array}{l}28 \\
62\end{array}$ & $\begin{array}{r}293 \\
78\end{array}$ & $\begin{array}{r}146 \\
.9\end{array}$ \\
\hline
\end{tabular}

The table 3.1 and table 3.3 are used to illustrate a graphical representation of the data, in MATLAB simulation.

MATLAB ( short for Matrix Laboratory) is a high level language and interactive environment that enhance computationally intensive tasks faster than with traditional programming languages such as FORTRAN, C and C++. It is used for numerical computation, visualization and programming in an easy to use atmosphere where problems and solutions are expressed in a simple mathematical notation. MATLAB today is a standard tools for scientist and engineers for computations, programming and research.. An additional package, Simulink, adds graphical multi-domain simulation and model-based design for dynamic and embedded system.

\subsection{EQUATIONS}

$A_{V}=X+Y+Z$ (Hours)

Where,

Av $=$ Monthly Average Hours of Sunshine (hours)

$\mathrm{X}=$ Year 2015

$\mathrm{Y}=$ Year 2016

$Z=$ Year 2017

$H=A_{v} \times 200 w(\mathrm{Whr})$

Where,

$\mathrm{H}=$ Power generated in a day using PV of 200watt (Whr)

$E=H \times$ No of days in the month 3

Where,

$\mathrm{E}=$ Power generated in a Month using PV of 2OOwatt (Whr)

$P_{L}=30 \% \times E$

Where,

$P_{L}=$ Power lossess on Power generated in Months using PV of 2OOwatt (Whr)

$A_{E}=E-P_{L}$

Where,

$A_{E}=$ Available Power in a Month (Whr)

$A_{P}=\frac{A_{E}}{L_{d}}$

Where,

$A_{P}=$ Available Hours of Power in a Month 
$L_{d}=\operatorname{Load}$

\subsection{CALCULATIONS}

Calculating for the first month of the year January for Yenagoa Sunshine per hour

From equation 1

Monthly Average Hours of Sunshine (hours)

$A_{V}=X+Y+Z$

$A_{V}=\frac{3.9+6.3+4.9}{3}=5.0 \mathrm{hr}$

From equation 3.2

Power generated in a day using PV of 2OOwatt (Whr)

$H=A_{v} \times 200 w$

$H=5.0 \times 200=1000(\mathrm{Whr})$

From equation 3.3

Power generated in a month using PV of 2OOwatt (Whr)

$E=H \times$ No of days in the month

$E=1000 \times 31=31000(\mathrm{Whr})$

From equation 3.4

Power losses On Power generated in a month using PV of 2OOwatt (Whr)

$P_{L}=30 \% \times 31000=9300(\mathrm{Whr})$

From equation 3.5

Available Power in a Month ((Whr)

$A_{E}=E-P_{L}$

$A_{E}=31000-9300=21700(\mathrm{Whr})$

From equation 3.6

Available Hours of power in a Month

$A_{P}=\frac{A_{E}}{L_{d}}$

Assuming a load of 200W

$A_{P}=\frac{21700}{200}=108.5$ hours $/$ month

\section{RESULTS AND DISCUSSION}

\subsection{TEST}

The testing was done by simulating the data gotten from the Nigerian meteorological agency (NiMET) using table 3.1 and table 3.3

The data shows the graphical representation of the sunshine in YENEGOA and PORT HARCOURT. The MATLAB code used in the study is shown in figure 4.1.

$>\mathrm{x}=[3.9,6.1,4.5,6,5,4.1,3,3.2,2.7,4,6.3,5.5] ;$

$>y=[6.3,3.6,5,3.8,4.6,3.8,2.9,2.1,3.2,4,6.3,6] ;$

$>\mathrm{z}=[4.9,4.9,5.6,4.4,5,1.9,1.3,1.4,1.9,4,5.7,5.3]$

$\gg \mathrm{t}=[1,2,3,4,5,6,7,8,9,10,11,12]$

> figure

$>$ hold on

> plot (t, x, 'blue', t, y, 'red', t, z, 'green')

And for Rivers State the code is

$>\mathrm{x}=[4.4,4,3.9,4.8,5.5,4.2,2.7,2,2.8,3.6,4.6,4.1]$

$>y=[5.8,5.0,4.1,5.4,4.9,4.0,2.5,2.9,3.1,4.3,5.6,5.7] ;$

$>\mathrm{z}=[5.2,6.2,4.2,5.3,5.1,3.0,3.1,1.3,2.0,2.8,5.8,5.7]$

> figure

> hold on

> plot(t, x, 'blue', t, y, 'red', t, z, 'green')

\subsection{RESULT}

The result is shown in figure 4.1 for Yenegoa.

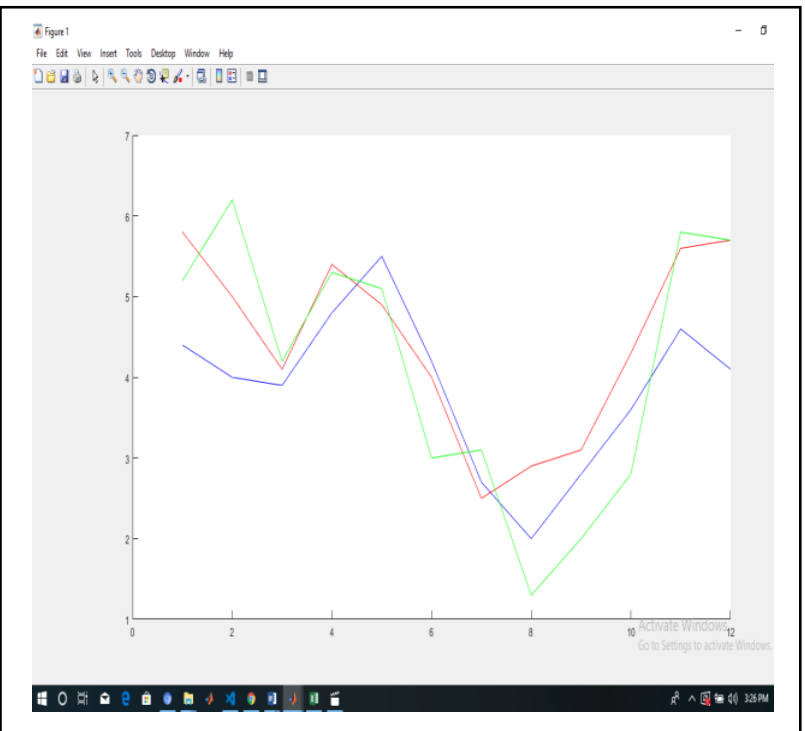


Figure 4.1: Graphical Result of the Data from Yenagoa.

Figure 4.1, shows the graph of sunshine hours in Yenagoa. From the graph the peak period of the year is from January to May and from October to December

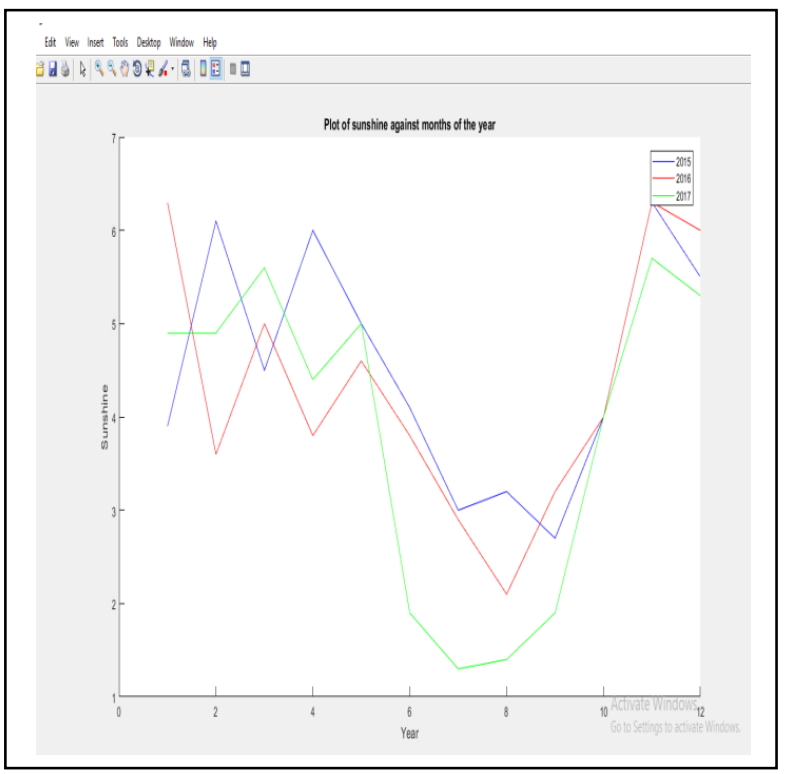

Figure 4.2: Graphical Result of the Data from Port Harcourt

Figure 4.2, shows the graph of sunshine hours in Port Harcourt. From the graph the peak period of the year is from January to May and from October to December. The lowest sunshine period is from July to August.

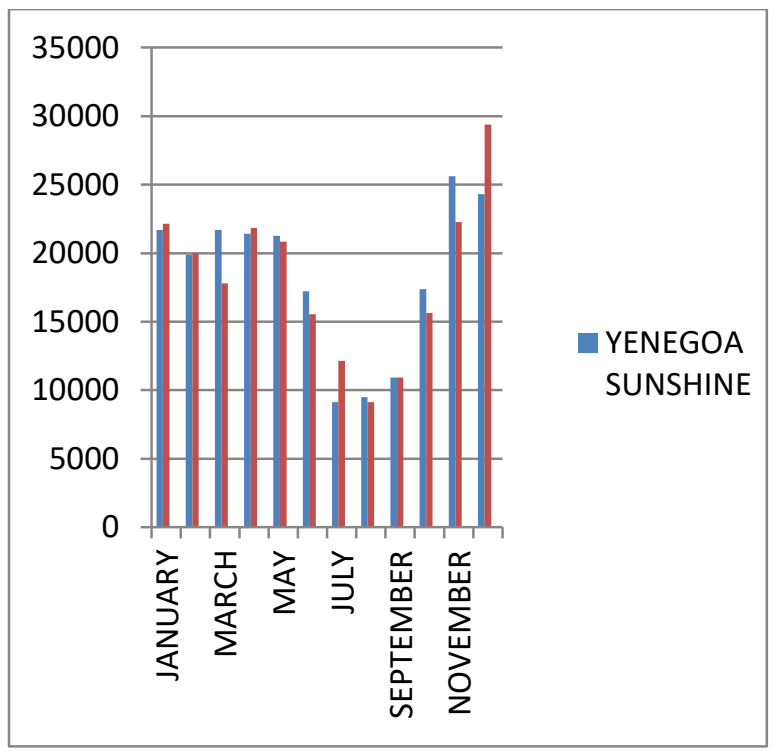

Fig 4.3: Available Power in a Month between Yenagoa and Port Harcourt.

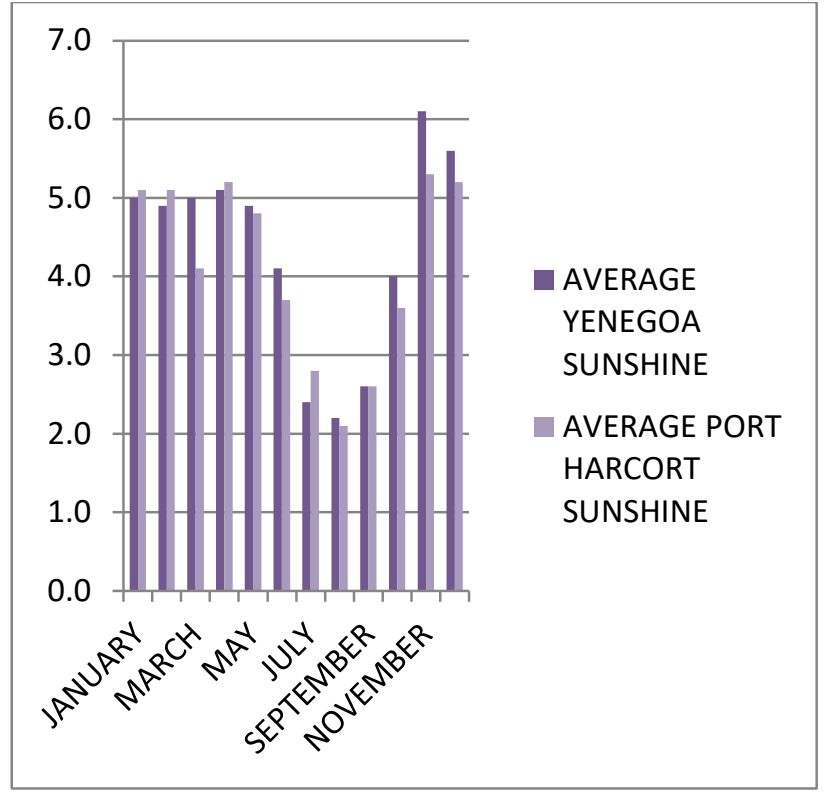

Fig 4.4: Monthly Average Sunshine Between Yenagoa and Port Harcourt for Year: 2015-2017

\section{CONCLUSION}

This study on assessment of solar energy resource in Niger delta (case study Port Harcourt and Yenagoa) was carried out using the sunshine per hour in Port Harcourt and Yenagoa. The data of the sunshine was gotten from the Nigerian meteorological agency (NiMET). The data gotten is used to run a simulation on MATLAB to show the high and low peak of the sunshine in Port Harcourt and Yenagoa.

The solar sunshine shows that solar energy can be harness to provide power to the residents of Port Harcourt and Yenagoa.

The research shows that Yenagoa city has more solar energy viability than Port Harcourt city. Yenagoa city has six months (March, May, June, August, October and November) of available power more than Port Harcourt while Port Harcourt has five months(January, February, April, July, and December) of available power than Yenagoa, while the month of September the available power was the same.

\section{REFERENCES}

[1] Nwabueze, I.O, Chinweike, E and Aliogor, O., 2010. Design and Construction of a Solar Electricity Generator. An unpublished undergraduate thesis, Enugu State University of Science and Technology Enugu, Nigeria.

[2] Paul, B., 2009. Variation in Light Intensity at Different Latitudes and Seasons, Effects of Clod Cover, and the Amount of Direct and Diffused Light. Proceeding of Continuous Cover Forestry Group (CCFG) Scientific Meeting, Westonbirt Arboretum, Gloucestershire.

[3] Agrafiotis, C. 2005. "Solar Water Splitting For Hydrogen Production with Monolithic Reactors". Solar 
Energy. 79 (4): 409

.Bibcode:2005SoEn...79..409A. doi:10.1016/j.solen er.2005.0026.

[4] Balcomb, J. and Douglas 1992. Passive Solar Buildings. Massachusetts Institute of Technology. ISBN 978-0-26202341-2

[5] Nasir, A. 2001. A Technology for Helping to Alleviate the Energy Problems; Solar Energy for Cooking and Power generation. 3rd Annual Engineering Conference of Federal University of Technology, Minna, Nigeria.

[6] Bradley, D. 1995. Plants Point the Way to Renewable Energy. New Sci 121(8)

[7] Sambo, A. S. 2001. Renewable Energy Technologies for National Development: Status, Prospects and Policy Directions. The Nigerian Engineer, 39(1), 23-31.

[8] Webb, J. 1995. By the Light of the Sun. New Sci. J. 121, 40.

[9] Abdulkarim, H. T. 2004. Techno-economic Analysis of Solar Energy for Electric Power Generation in Nigeria.

[10] Leibowitz, L., and Hanseth, E. 1982. Solar thermal technology-outlook for the 80s. Mech. Eng. 104

[11] Stone, J. L. 1993. Photovoltaics: Unlimited Electrical Energy from the Sun. Physics Today 46(9)

[12] Ajayi, A. B. 2009. A Survey of Solar Energy Power Systems. 8th EEEIC International Conference on Environment and Electrical Engineering, Karpacz, Poland, pp. 187-190.

[13] Walters, S. 1977. Low Loss Energy Storage Flywheel. Mech. Eng. J. 99, 48

[14] Hoff, E., and Cheney, M. 2000. The Idea of Low Cost Photovoltaic. Energy Journal, 93, 17

[15] Jesuleye, A.O. and Siyanbola, W.O. 2008. Solar Electricity Demand Analysis for Improved Access to Electricity in Nigeria. Nigeria Journal of Solar Energy. Vol. 19(1): pp 136-141

[16] Okafor, E.C.N. and Joel-Uzuegbu, C.K.A. 2010. Challenges to Development of Renewable Energy for Electric Power Sector in Nigeria. International Journal of Academic Research. Vol. 2(2): pp 211-216.

[17] Fadare, D.A. 2009. Modelling of Solar Energy Potential in Nigeria Using An Artificial Neural Network Model. Journal of Applied Energy, Science Direct. 86(9), 1410-1422

[18] Sambo, A. S. 2008. The Role of Energy in achieving Millenium Development Goals (MDG): Keynote Address of the National Engineering Conference (NETEC), Ahmadu Bello University, Zaria.
[19] The Nigerian Meteorological Agency (NiMET) - Abuja, Nigeria 